BARBARA IMIELSKA

Uniwersytet Kard. Stefana Wyszyńskiego w Warszawie

\title{
Pogrzeb DZIECI PORONIONYCH I MARTWO URODZONYCH W ŚWIETLE PRZEPISÓW PRAWA POLSKIEGO ORAZ NORM KANONICZNYCH
}

Śmierć dziecka jest dla rodziców niezwykle bolesnym przeżyciem. Dotyczy to również sytuacji, kiedy następuje ona przed jego narodzeniem. Stąd też prawo, które ma służyć człowiekowi, powinno zawierać regulacje pozwalające rodzinie zmarłego dziecka właściwie przeżyć to smutne wydarzenie. Każdy porządek prawny, czy to państwowy, czy kościelny, powinien uwzględniać wymagania naturalnych uprawnień, które każdy człowiek posiada od momentu poczęcia. Chodzi tutaj zarówno o uprawnienia rodziców do pożegnania swojego nienarodzonego dziecka i pochówku jego doczesnych szczątków, jak i o prawo zmarłego do pogrzebu.

Zagadnienie pochówku dzieci poronionych i martwo urodzonych należy do uprawnień naturalnych, dlatego powinno znaleźć swoje odzwierciedlenie w stosownym ustawodawstwie. Zasadniczo prawo powinno regulować dwie kwestie: pogrzeb dziecka martwo urodzonego lub poronionego oraz pogrzeb dziecka, które zostało utracone $\mathrm{w}$ wyniku procedury zapłodnienia in vitro, aborcji czy też wskutek badań naukowych prowadzonych na niezaimplementowanych ludzkich zarodkach. 
U podstaw legislacji powinna leżeć personalistyczna koncepcja człowieka, zakładająca, iż jest on osobą od początku swego istnienia, w związku z czym przysługują mu konkretne prawa, zwłaszcza prawo do życia. Warto zauważyć, że zarówno ustawodawca kościelny, jak i państwowy, poczynili pewne kroki prawne uwzględniające taką wizję człowieka. Na gruncie prawa kanonicznego było to podjęcie problemu pochówku dzieci zmarłych przed chrztem, co wpłynęło na kształt liturgii pogrzebu. Nowelizacja w prawie polskim dotyczyła głównie uściślenia, że każdy rodzic ma prawo pochować swoje zmarłe przed narodzeniem dziecko niezależnie od czasu trwania ciąży. Prawo to obejmuje zgodę na wydanie zwłok dziecka oraz wszelkiej dokumentacji umożliwiającej pochówek.

Niemniej obecny stan prawny wymaga jeszcze zmian, które przyczyniając się do godnego traktowania dziecka nienarodzonego, zagwarantowałyby również traktowanie z należytym szacunkiem rodziców oraz wszystkich osób dobrej woli, które bezinteresownie podejmują troskę o zwłoki zmarłych dzieci pozostawione w szpitalu.

\section{Godność dziecka poczętego ujmowana w kategoriach personalistycznych}

Godność dziecka poczętego, stanowiąca temat wielu dyskusji, niejednokrotnie jest podważana lub negowana. Tymczasem bez stanowczego stwierdzenia, iż dziecko poczęte jest człowiekiem i osobą od początku swojego istnienia i że w związku z tym przysługują mu wszystkie wynikające $z$ tego faktu prawa, wszelka dyskusja dotycząca ochrony życia oraz innych podstawowych praw nie ma sensu. Stąd też należy przyjąć, że człowiek już w łonie 
matki obdarzony jest niezbywalną godnością, której nikt nie może podważyć, a tym bardziej odebrać. Jeżeli przyjmiemy dodatkowo, że człowiek stwarzany jest przez Boga i na Jego podobieństwo, to ta nadprzyrodzona rzeczywistość staje się podstawą niezbywalnej wartości ludzkiego życia. Dlatego człowiek już od poczęcia ma prawo do życia, atakże ochrony zdrowia, opieki medycznej, narodzin, wzrastania w rodzinie i innych podstawowych praw.

Przyjęcie jakichkolwiek innych niż poczęcie kryteriów człowieczeństwa prowadzi do ujmowania człowieka w sposób wykluczający go z grona osób. Nie można przyjąć, iż dane kryterium rozwojowe bądź jakaś cecha deskryptywna sprawia, że człowiek staje się osobą. Osoba nie zaczyna istnieć później niż człowiek i nie przestaje istnieć wcześniej. Bycie osobą nie jest wynikiem rozwoju. Należy zauważyć, że już od momentu zapłodnienia istnieje zarodek, który wykazuje podstawową cechę żywego organizmu, a mianowicie stały, z góry określony szlak rozwojowy ${ }^{2}$. Od samego początku mamy do czynienia z samoorganizującym się organizmem, zróżnicowanym biologicznie i chemicznie. W wyniku zapłodnienia powstaje nowy człowiek, genetycznie już okreśłony, rozwijający się w trakcie swego życia. Dlatego istnieje tylko jedno kryterium bycia osobą: biologiczna przynależność do rodzaju ludzkiego. W świetle tego kryterium początku i końca bycia osobą nie można oddzielić od początku i końca bycia człowiekiem³.

${ }^{r}$ Zob. R. Spaemann, Osoby. O różnicy między kims, a czymś, tłum. J. Merecki, Warszawa 2001, s. 302.

2 Zob. J. de Dios Vial Correa, Embrion ludzki jako organizm i jako ktoś spośód nas, [w:] Medycyna i prawo: za czy przeciw życiu?, red. E. Sgreccia, T. Styczeń, Lublin i 999, s. 66.

3 Zob. T. Biesaga, Status embrionu - stanowisko personalizmu ontologicznego, „Medycyna Praktyczna” (7-8/2004), s. 30. 
Embrion ludzki nie jest człowiekiem potencjalnym, ponieważ od początku należy do rodziny ludzkiej na podstawie genealogicznego z nią pokrewieństwa4. Uznanie należnych mu praw nie może być wynikiem akceptacji bądź nieakceptacji jego człowieczeństwa przez społeczeństwo, gdyż prawa osoby przysługują każdemu w taki sam sposób na podstawie prawa naturalnego.

Jeżeli przyjmiemy, że każde dziecko od chwili swojego poczęcia jest osobą, to niezależnie od fazy jego rozwoju i stanu zdrowia jego pierwszym i podstawowym prawem jest prawo do życia od naturalnego poczęcia do naturalnej śmierci. Prawo każdego dziecka poczętego do do bycia , urodzonym i wychowanym w rodzinie, nie może być mu odebrane, ponieważ jest to prawo podstawowe człowieka. Z prawa do życia wynikają również: prawo do rozwoju, także w łonie matki, ochrony zdrowia, dziedziczenia, nietykalności osobistej. Prawa te gwarantowane są przez ustawodawstwo zarówno państwowe, jak i międzynarodowe.

Do aktów międzynarodowych wyznaczających standardy co do stosowania praw człowieka także wobec dzieci, należą między innymi Powszechna Deklaracja Praw Człowieka, gdzie w art. 3 czytamy, iż każdy człowiek ma prawo do życia, wolności i bezpieczeństwa swej osoby5, oraz Konwencja o ochronie praw człowieka i podstawowych wolności z I950r., która już w art. I zwraca uwagę na fakt, że nikt nie może być umyślnie pozbawiony życia, a prawo to, przynależne każdemu człowiekowi,jest chronione od-

\footnotetext{
${ }_{4}$ Zob. R. Spaemann, Osoby. O różnicy między kimś a czyms, tłum.J. Merecki, Warszawa 200I, s. 294.

5 Zob. Powszechna Deklaracja Praw Człowieka, przyjęta i proklamowana rezolucja Zgromadzenia Ogólnego ONZ 2 I $7 \mathrm{~A} / \mathrm{III}$ z dnia ro grudnia I948, w: Wybór dokumentów do nauki prawa międzynarodowego, K. Kocot, K. Wolfke (oprac.), Warszawa I 978, s. 97-ıо2.
} 
powiednim aktem normatywnym ${ }^{6}$. Potwierdzenie prawa dziecka do korzystania ze szczególnej ochrony, zwłaszcza w sferze rozwoju fizycznego, umysłowego, moralnego, duchowego i społecznego, ze szczególnym poszanowaniem jego wolności i godności, znajduje się także w Deklaracji Praw Dziecka z I959 r. Zasada 4, zawarta $\mathrm{w}$ tym dokumencie, postuluje o zagwarantowanie dziecku prawa do opieki zarówno przed jak i po urodzeniu. Ochrony i pomocy należy domagać się nie tylko wobec samego dziecka, ale i całej rodziny jako naturalnej oraz podstawowej komórki społecznej, zwłaszcza w okresie trwania jej odpowiedzialności za opiekę i wychowanie dziecił. Przyrodzone prawo do życia podkreśla również w art. 6 Międzynarodowy Pakt Praw Obywatelskich i Politycznych z I966 r. ${ }^{8}$. Zaznaczone jest w nim ponadto, że prawo to jest prawem podmiotowym (art. 16).

Uznanie wrodzonej godności, równych i niezbywalnych praw wszystkich ludzi oraz faktu, iż dzieci mają prawo do szczególnej troski i pomocy, zostało zapisane w Konwencji o Prawach Dziecka z dnia 20 listopada r989 roku ${ }^{9}$.

${ }^{6}$ Zob. Konwencja o ochronie praw człowieka i podstawowych wolności, sporządzona w Rzymie dnia 4 listopada I950 r., zmieniona następnie Protokołami nr 3, 5 i 8, oraz uzupełniona Protokołem nr 2 (Dz. U. I 993 nr 6I poz. 284).

7 Zob. Międzynarodowy Pakt Praw Obywatelskich i Politycznych, otwarty do podpisu w Nowym Jorku dnia I 9 grudnia I 966 r. (Dz. U. I 977 nr 38 poz. I67).

${ }^{8}$ Zob. Międzynarodowy Pakt Praw Obywatelskich i Politycznych otwarty do podpisu w Nowym Jorku dnia I 9 grudnia i 966, (Dz. U. I977, Nr 38 , poz. I67).

${ }_{9}$ Zob. Konwencja o prawach dziecka, przyjęta przez Zgromadzenie Ogólne Narodów Zjednoczonych dnia 20 listopada I 989 r. (Dz. U. I99 I nr I 20 poz. 526). 
Pojęcie „przyrodzonej godności człowieka” jest jednym z podstawowych terminów występujących w Konstytucji Rzeczypospolitej Polskiej. Godność w ujęciu konstytucyjnym stanowi właściwość osoby nabytą na początku jej istnienia, a zatem należy do zbioru wartości uniwersalnych, wspólnych wszystkim ludziom. Art. 30 Konstytucji Rzeczypospolitej Polskiej charakteryzuje godność człowieka jako „źródło wolności i praw człowieka i obywatela” $\mathrm{i}$ jest jedną z klauzul generalnych, stanowiących podstawę interpretacyjną całego systemu prawa. Co więcej, godność nie może zostać z niego usunięta, gdyż jest pierwotna wobec aktu prawnego, który o niej stanowi.

Godność osoby, zgodnie z art. 23 Kodeksu cywilnego, jest dobrem osobistym, a zatem przysługuje każdemu człowiekowi, i jest chroniona przez prawo ${ }^{\text {II }}$. Także Kodeks karny w art. 216 §I kwalifikuje naruszenie czyjejś godności jako przestępstwo znieważenia, czyli czyn zabroniony, szkodliwy społecznie, a co za tym idzie karalny ${ }^{\mathrm{r} 2}$. Tak rozumiana godność nie podlega wartościowaniu, a jej ochrona jest zasadniczo zagwarantowana przez prawo polskie.

W tym kontekście także prawo dziecka poczętego do poszanowania jego godności powinno być ustawowo potwierdzone i chronione. Należy zauważyć, że w prawie polskim ochrona praw dzieci nienarodzonych w głównej mierze prowadzona jest na drodze interpretacji ustaw szczególnych, a nie w ujęciu konstytucyjnym. Powodem takiego stanu rzeczy jest między innymi brak

\footnotetext{
Io Konstytucja Rzeczypospolitej Polskiej z dnia 27 kwietnia I997 r. (Dz. U. I 997 nr 78 poz. 483 z późn. zm.).

I Ustawa z dnia 23 kwietnia I 964 r. Kodeks cywilny (Dz. U. z i 964 nr I 6 poz. 93 z późn. zm.).

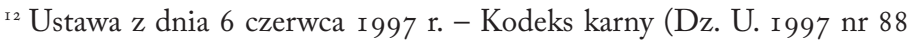
poz. 553 z późn. zm.).
} 
definicji określającej, od którego momentu w świetle prawá mamy do czynienia z człowiekiem, co daje możliwość stosowania różnego rodzaju koncepcji określających moment stawania się osobą. W ustawodawstwie polskim podaje się definicję słowa „dziecko”, którym jest każda istota ludzka od poczęcia do osiągnięcia pełnoletnościris. Niemniej twierdzenie wydaje się być pomijane w innych aktach normatywnych, pozbawiając je tym samym spójności w tak podstawowej kwestii jak prawa osoby.

Kościół realizuje powierzoną przez Chrystusa misję głoszenia Ewangelii, we właściwy sobie sposób obejmując troską człowieka (por. Mk I6, 15), chroniąc jego godność, wynikającą ze stworzenia go na obraz i podobieństwo Boże. Godność nadana człowiekowi przez Boga nigdy nie może zostać mu odebrana. Co więcej, on także nie może się jej zrzec, gdyż nie pochodzi ona od niego. Jej potwierdzeniem jest odkupienie dokonane przez Chrystusa za każdego człowieka. To w Nim objawiła się bezgraniczna miłość Boga nadająca wartość każdej osobie.

\section{Dziecko nienarodzone w prawie polskim}

Tak jak zostało to już wcześniej zaznaczone, prowadząc rozważania dotyczące statusu dziecka nienarodzonego w prawie polskim, trzeba przyjąć założenie, iż dziecko jest osobą, i to od początku swojego istnienia, a nie od jakiegokolwiek innego momentu rozwoju. Stąd też w ustawach dotyczących prawa do życia należy zachowywać przede wszystkim uniwersalność i niezbywalność tego prawa. Należy przy tym odrzucić pogląd, że aby cieszyć się

${ }^{13}$ Ustawa z dnia 6 stycznia 2000 r. o Rzeczniku Praw Dziecka (Dz. U. 2000 nr 6 poz. 69 z późn. zm.). 
prawem do życia, nie wystarczy być istotą ludzką, lecz trzeba jeszcze spełniać inne warunki $i^{\mathrm{i4}}$.

Dopiero w tym kontekście można stwierdzić, że prawa dzieci nienarodzonych posiadają wymiar normatywny, który wynika z przyjęcia określonej wizji człowieka. Stąd też należy mówić o przysługującej dziecku nienarodzonemu podmiotowości prawnej.

Rzeczywiście, polskie prawo gwarantuje dziecku poczętemu pewne uprawnienia, uznając życie za fundamentalne dobro człowieka, o które zarówno państwo, jak i społeczeństwo powinny się troszczyćc ${ }^{15}$. Ustawodawca wskazując, iż prawo do życia podlega ochronie, zaznacza, że dotyczy to również fazy prenatalnej ludzkiego życia. A zatem implicite zrównuje prawo do życia dziecka poczętego nienarodzonego z prawem dziecka urodzonego.

Istniejące w prawie polskim uprawnienia przysługujące dziecku poczętemu wynikają w głównej mierze z regulacji Kodeksu cywilnego oraz Kodeksu rodzinnego i opiekuńczego ${ }^{\text {I6 }}$.

${ }^{14}$ Zob. T. Bertone, Catholics and pluralist society: "imperfect laws” and the responsibility of legislators, w: „Evangelium vitae”: Five Years of confrontation with the society, red. J. Correa, E. Sgreccias, Vatican 2000, s. 2 I 5.

I5 Ustawa z dnia 7 stycznia I993 r. o planowaniu rodziny, ochronie płodu ludzkiego i warunkach dopuszczalności przerywania ciąży (Dz. U. I 993 nr I 7 poz. 78 z późn. zm.).

${ }^{16}$ Zob.:

art. 446 I k.c., w którym wskazuje się, że dziecko może żądać naprawienia szkód doznanych przed urodzeniem (ekspektatywa prawa do odszkodowania);

art. 927 k.c., stwierdzający, iż dziecko poczęte może być spadkobiercą, jeśli urodzi się żywe (ekspektatywa prawa do spadku);

art. Io $\oint_{4}$ k.r.o., wskazujący, że mąż nie może żądać unieważnienia małżeństwa $\mathrm{z}$ powodu braku przepisanego wieku, jeśli żona zaszła w ciążę (prawo do życia w rodzinie); 


\section{Uprawnienia rodziców wynikające $\mathrm{z}$ faktu poronienia lub martwego urodzenia dziecka na gruncie prawa cywilnego}

Poronienie niejednokrotnie traktowane jest w świadomości społecznej jako zabieg medyczny. Jego przyczynę stanowi szereg czynników mających niekorzystny wpływ na prawidłowy przebieg ciąży oraz prowadzące do jej utraty powikłania. Niemniej według zaleceń Polskiego Towarzystwa Ginekologicznego ciąża ma być chroniona od samego początku ${ }^{\text {t7. }}$.

W nomenklaturze prawnej nie da się oddzielić jednoznacznie poronienia od porodu. Można przyjąć kryterium czasowe wskazujące, do którego tygodnia ciąży mamy do czynienia z poronieniem, a od którego już z porodem. Drugim kryterium jest kryterium wagowe. Określa ono, ile musi ważyć płód, by mógł przeżyć poza organizmem matki. W praktyce stosuje się zasadę, iż do 22. tygodnia ciąży następuje poronienie, zaś po 22. tygodniu

art. 5 I 5 k.r.o., określający, że spadkobierca (w tym dziecko poczęte) zmarłego małżonka może być stroną w postępowaniu o wyrównanie dorobków $\mathrm{z}$ racji na małżeńską umowę majątkową (pochodne prawo do wyrównania dorobków);

art. 75 k.r.o., przewidujący możliwość uznania dziecka poczętego (prawo do ojca);

art. I4 I k.r.o., określający obowiązek alimentacyjny ojca, niebędącego mężem matki, w zakresie pokrycia wydatków związanych z ciążą i porodem (pochodne prawo do alimentacji);

art. I 82 k.r.o., ustanawiający kuratelę dla dziecka poczętego, ale jeszcze nieurodzonego, w celu strzeżenia przyszłych praw dziecka (prawo do ochrony istniejących i przyszłych praw).

${ }^{17}$ Zob. Polskie Towarzystwo Ginekologiczne, Rekomendacje Polskiego Towarzystwa Ginekologicznego w zakresie opieki przedporodowej w ciąży o prawidłowym przebiegu, www.femmed.com.pl/wp-content/uploads/ 2013/o2/rekomendacjaopiekaprzedporodowa.pdf(6.03.2017). 
ciąży mówimy o porodzie. Zgodnie z kryterium wagowym dopiero w przypadku dziecka o wadze powyżej 600 gramów uważa się, iż nastąpił poród ${ }^{18}$.

W Rozporządzeniu Ministra Zdrowia z dnia 9 listopada $2015 \mathrm{r}$. w sprawie rodzajów, zakresu i wzorów dokumentacji medycznej oraz sposobu jej przetwarzania ${ }^{\text {I9 }}$ czytamy, że w przypadku poronienia dochodzi do wydalenia lub wydobycia $z$ ustroju matki płodu, który nie wykazuje żadnego znaku życia, jeśli nastąpiło ono przed upływem 22. tygodnia ciąży (2I tygodni i 6 dni). Urodzenie martwe natomiast jest zdefiniowane jako zgon dziecka po upływie 22. tygodnia ciąży lub później. Przytoczone definicje są stosowane przy dokonywaniu wpisów do dokumentacji medycznej, ale nie mają zastosowania przy wypisywaniu karty zgonu czy zgłoszenia urodzenia dziecka, ponieważ dokumenty te nie stanowią dokumentacji medycznej.

Bezpośrednio po poronieniu czy martwym urodzeniu dziecka tylko jego rodzice mają prawo podjąć decyzję o tym, co stanie się z jego ciałem. Jeżeli zdecydują się na pozostawieniu szczątków w szpitalu, wówczas na placówce medycznej spoczywa obowiązek przekazania ich do pochówku. Zgodnie z § 7 Rozporządzenia Ministra Zdrowia $z$ dnia 7 grudnia 200 r. w sprawie postępowania ze zwłokami i szczątkami ludzkimi ${ }^{20}$ zwłoki dzieci martwo urodzonych, nieodebrane przez rodziców, szpital może przekazać

${ }^{18}$ Ustawa $\mathrm{z}$ dnia 28 listopada 20 I 4 r. Prawo o aktach stanu cywilnego (Dz. U. 2014 nr o poz. I74I z późn. zm.).

${ }^{19}$ Rozporządzenie Ministra Zdrowia z dnia 9 listopada 20 I 5 r. w sprawie rodzajów, zakresu i wzorów dokumentacji medycznej oraz sposobu jej przetwarzania (Dz. U. 2015 nr o poz. 2069).

${ }^{20}$ Rozporządzenia Ministra Zdrowia z dnia 7 grudnia 200 I r. w sprawie postępowania ze zwłokami i szczątkami ludzkimi (Dz. U. 200 I nr I53 poz. I 783 z późn. zm.). 
w celach pochówkowych każdej osobie, która się do tego zobowiąże. W myśl art. Io Ustawy z dnia 3I stycznia 1959 r. o cmentarzach i chowaniu zmarlych ${ }^{21}$, jeśli żaden z podmiotów uprawnionych nie skorzysta z prawa do pochowania zwłok dziecka, zobowiązane są do tego ośrodki pomocy społecznej. Ponadto matka dziecka ma prawo do uzyskania wszelkich informacji, a także dokumentacji medycznej, zarówno swojej, jak I dotyczącej swojego zmarłego dziecka, co gwarantują odpowiednie akty normatywne ${ }^{22}$.

Wraz z wydaniem przez szpital ciała dziecka rodzice powinni otrzymać pisemne zgłoszenie urodzenia dziecka, wystawione przez lekarza, położną lub zakład opieki zdrowotnej, a także kartę martwego urodzenia dziecka. Czas trwania ciąży, wiek czy waga dziecka nie są podstawą odmowy wydania przez szpital czy urząd stanu cywilnego (USC) dokumentów potrzebnych do pochowania zwłok dziecka. Niezależnie od tego, czy mamy do czynienia z poronieniem, czy z porodem martwego dziecka, rodzice maja prawo do rejestracji urodzenia dziecka w USC. Prawo do rejestracji dotyczy również poronień i porodów, które odbyły się w domu. W takim wypadku dokumenty dla USC powinien wystawić szpital (lekarz lub położna), do którego zgłosiła się kobieta po poronieniu ${ }^{23}$. Identyczne prawo przysługuje, gdy poronienie lub martwe urodzenie dziecka miało miejsce poza granicami Polski. Nieistotny jest tutaj także czas trwania ciąży.

${ }^{21}$ Ustawa z dnia 3 I stycznia I 959 r. o cmentarzach i chowaniu zmarłych, (Dz. U. I 959 nr I I poz. 62 z późn. zm.); tekst jednolity (Dz. U. 2015 nr o poz. 2 I 26).

${ }^{22}$ Aktami tymi są np. Ustawa $z$ dnia I 5 kwietnia 20 I I r. o działalności leczniczej (Dz. U. 2 o I I nr I I 2 poz. 654 z późn. zm.) czy Ustawa o zawodzie lekarza z dnia 5 grudnia I 996 r. (Dz. U. I 997 nr 28, poz. I 52 z późn. zm).

${ }^{23}$ Ustawa $z$ dnia 28 listopada 20 I 4 r. Prawo o aktach stanu cywilnego (Dz. U. 2014 nr o poz. I 74I). 
Rejestracja odbywa się za pośrednictwem konsula (jeśli to konieczne), a urzędem właściwym do dokonania rejestracji jest wtedy USC Warszawa-Śródmieście ${ }^{24}$.

Pisemne zgłoszenie urodzenia dziecka wypełnia się na podstawie ustawy Prawo o aktach stanu cywilnego ${ }^{25}$. Przy wypisywaniu pisemnego zgłoszenia urodzenia dziecka, dokumentu niezbędnego do uzyskania aktu urodzenia, muszą być wypełnione rubryki dotyczące wagi i płci dziecka oraz czasu trwania ciąży. W przypadku poronień na bardzo wczesnym etapie ciąży istnieją jednak obiektywne trudności z ustaleniem płci. Na wczesnym etapie ciąży nie jest to możliwe bez przeprowadzenia badań genetycznych. Dopiero na tej podstawie USC wystawia akt urodzenia dziecka $\mathrm{z}$ adnotacją, że urodziło się martwe. Zastępuje on akt zgonu, którego w tym wypadku nie sporząadza się dodatkowo. Przekroczenie ustawowych terminów na dokonanie rejestracji (np. z powodu oczekiwania na wyniki badań) nie pozbawia prawa do dokonania jej później ${ }^{26}$.

Dawniej rodzice posiadali możliwość zdecydowania się na płatne badania genetyczne lub zastosowania tzw. procedury uprawdopodobnienia płci, w której płeć dziecka określana była na podstawie odczuć matki. Obecnie zmieniono przepisy, uzależniając wydanie dokumentów koniecznych do rejestracji od określenia płci. Nie zobowiązują one jednak szpitali, by przechowywały zwłoki dzieci poronionych lub martwo urodzonych przez czas potrzebny rodzicom do podjęcia w pełni świadomej decyzji

\footnotetext{
${ }^{24}$ Ustawa $\mathrm{z}$ dnia 28 listopada $2014 \mathrm{r}$. Prawo o aktach stanu cywilnego (Dz. U. $2014 \mathrm{nr}$ o poz. I74I).

${ }^{25}$ Ustawa z dnia 28 listopada 2014 r. Prawo o aktach stanu cywilnego (Dz. U. $2014 \mathrm{nr}$ o poz. I74I).

${ }^{26}$ Ustawa $\mathrm{z}$ dnia 28 listopada $2014 \mathrm{r}$. Prawo o aktach stanu cywilnego (Dz. U. $2014 \mathrm{nr}$ o poz. I74I).
} 
o badaniu genetycznym ${ }^{27}$. Nowe przepisy nie zawierają norm, $\mathrm{w}$ świetle których prawo do rejestracji dziecka byłoby uzależnione od stwierdzenia obecności tkanek płodu. A zatem stawianie takiego warunku rodzicom nie posiada podstawy prawnej, tym bardziej że szczątki płodu na ogół nie są przekazywane do badania histopatologicznego.

Z kartą martwego urodzenia dziecka należy zgłosić się do urzędu stanu cywilnego. Tam wystawiany jest odpis skrócony aktu urodzenia $\mathrm{z}$ adnotacją o urodzeniu martwym. W takiej sytuacji nie wystawia się aktu zgonu. Dokumentem uprawniającym do pochowania zwłok dziecka poronionego lub martwo urodzonego jest karta zgonu $^{28}$.

Niezależnie od tego, czy doszło do poronienia, czy do martwego urodzenia dziecka, kobiecie przysługuje prawo do zasiłku i urlopu macierzyńskiego od dnia śmierci dziecka w wymiarze od siedmiu dni do ośmiu tygodni (art. I8o kp) ${ }^{29}$. Uzyskuje się go na podstawie wydanego przez USC aktu urodzenia dziecka $\mathrm{z}$ adnotacją o urodzeniu martwym. Prawo to uzależnione jest od pozostawania w stosunku pracy lub podlegania właściwym ubezpieczeniom z innego tytułu. Działaniem wystarczającym do skorzystania $z$ tych praw jest przedstawienie pracodawcy aktu urodzenia $z$ adnotacją o martwym urodzeniu.

Ponadto kobiecie przysługuje ponadto prawo do uzyskania zasiłku pogrzebowego. W tym celu należy w ZUS-ie przedstawić akt urodzenia dziecka $z$ adnotacją o jego martwym urodzeniu,

${ }_{27}$ Zob. Stowarzyszenie Rodziców po Poronieniu, Prawo w pigutce, w: https://www.poronienie.pl/prawo/prawo-w-pigulce/ (Io.o3.20 I 7r.)

${ }^{28}$ Ustawa $z$ dnia 28 listopada 20 I 4 r. Prawo o aktach stanu cywilnego (Dz. U. 20I 4 nr o poz. I74I z późn. zm.).

${ }^{29}$ Zob. Ustawa z dnia 26 czerwca I 974 Kodeks pracy (Dz. U. I974 nr 24 poz. I4 I z późn. zm.). 
dokumenty potwierdzające poniesienie kosztów pochówkư oraz dokument potwierdzający prawo do świadczeń. W przypadku braku aktu urodzenia dziecka niemożliwe jest uzyskanie zasiłku pogrzebowego ${ }^{30}$.

\section{Pogrzeb dzieci poronionych i martwo urodzonych w świetle ustawodawstwa państwowego}

Pogrzeb dziecka martwo urodzonego jest możliwy bez względu na czas, w którym doszło do jego śmierci. W celu pochówku rodzice mogą w ciągu 48 godzin od zgonu dziecka wystąpić o wydanie jego zwłok ${ }^{31}$. Mają też prawo otrzymać kartę martwego urodzenia dziecka, w której stwierdza się fakt zgonu i jego przyczynę. Karta wydawana jest przez lekarza po oględzinach, o czym mówi art. II ustawy o zmianie ustawy o cmentarzach i chowaniu zmarłych $\mathrm{Z} 2 \mathrm{OII}$ roku $^{32}$.

Rodzice mają prawo do pochowania zarówno ciała jak i szczątków dziecka bez względu na czas trwania ciąży. Szpital wydaje w celach pochówkowych kartę zgonu, która jest potrzebna zarządcy cmentarza. Prawo do pochówku nie jest uzależnione od prawa do rejestracji w ZUS. Można dziecko zarejestrować

\footnotetext{
$3^{30}$ Ustawa z dnia I 7 grudnia I 998 r. o emeryturach i rentach z Funduszu Ubezpieczeń Społecznych (Dz. U. I 998 nr I62 poz. i I 8 z późn. zm.).

${ }^{31}$ „Za zwłoki uważa się ciała osób zmarłych i dzieci martwo urodzonych bez względu na czas trwania ciąży; Zob. Rozporządzenie Ministra Zdrowia z 2 I grudnia 2006 r. zmieniające rozporządzenie w sprawie postępowania ze zwłokami i szczątkami ludzkimi (Dz. U. 2006 nr I poz. Io z późn. zm.),

${ }^{32}$ Ustawa o zmianie ustawy o cmentarzach i chowaniu zmarłych $z$ dnia 26 maja 20 I (Dz. U. 20 I nr I44 poz. 853).
} 
i pochować, można też poprzestać na samej rejestracji lub na samym pochówku33.

Prawo do pochowania zwłok dzieci martwo urodzonych, jak wskazuje art. Io ust. I Ustawy z dnia 3I stycznia 1959 r. o cmentarzach i chowaniu zmarłych ${ }^{34}$, oprócz rodziców ma najbliższa rodzina, czyli krewni wstępni i zstępni oraz krewni do czwartego stopnia w linii bocznej. Gdyby osoby te nie chciały lub nie mogły dokonać pochówku, wtedy prawo pochowania zwłok przysługuje osobom, które się do tego dobrowolnie zobowiążą. Na wniosek osób wymienionych wyżej zwłoki lub szczątki dziecka mogą zostać spopielone przez zakłady opieki zdrowotnej.

Zwłoki dzieci mogą być chowane w grobach dopuszczonych przez odpowiednie akty prawne. O możliwych sposobach grzebania zwłok dzieci mówią akty prawne: Ustawa o zmianie ustawy o cmentarzach i chowaniu zmarłych ${ }^{35}$; Rozporządzenie Ministra Zdrowia $z$ dnia 7 grudnia $200 \mathrm{r}$ r. w sprawie postępowania ze zwłokami i szczątkami ludzkimi ${ }^{36}$; Rozporządzenie Ministra Infrastruktury w sprawie wymagań, jakie muszą spełniać cmentarze, groby i inne miejsca pochówku zwłok i szczątków37.

33 Ustawa z dnia 3 I stycznia I 959 r. o cmentarzach i chowaniu zmarłych (Dz. U. I959 nr i I poz. 62).

34 Ustawa $z$ dnia 3 I stycznia I 959 r. o cmentarzach i chowaniu zmarłych (Dz. U. I959 nr I I poz. 62).

35 Ustawa o zmianie ustawy o cmentarzach i chowaniu zmarłych $z$ dnia 26 maja 20I I (Dz. U. 20I I nr I44 poz. 853 z późn. zm.).

${ }^{36}$ Rozporządzenie Ministra Zdrowia $z$ dnia 7 grudnia 200 I r. w sprawie postępowania ze zwłokami i szczątkami ludzkimi (Dz. U. 200 I nr I 53 poz. I783).

${ }_{37}$ Rozporządzenie Ministra Infrastruktury z dnia 7 marca 2008 r. w sprawie wymagań, jakie muszą spełniać cmentarze, groby i inne miejsca pochówku zwłok i szczątków (Dz. U. 2008 nr 48 poz. 284). 


\section{Pogrzeb kościelny dzieci poronionych i martwo urodzonych}

Kościół od zawsze bronił osobowej godności człowieka i zwracał uwagę na konieczność szacunku dla jego ciała, które jest świątynią Ducha Świętego (I Kor 6, I9). Znajduje to swoje odzwierciedlenie w Katechizmie Kościoła katolickiego, w którym czytamy, iż „Ciała zmarlych powinny być traktowane z szacunkiem i miłością wypływającą z wiary i nadziei zmartwychwstania. Grzebanie zmarłych jest uczynkiem miłosierdzia względem ciała; jest uczczeniem dzieci Bożych, będących świątynią Ducha Świętego"(KKK 2300).

Zagadnienie pochówku, istniejące na przestrzeni wieków, wymagało od wspólnoty Kościoła podjęcia refleksji prawnej celem wypracowania odpowiednich regulacji w zmieniającej się sytuacji społecznej i kulturowej. Ostateczne unormowanie tego problemu zawiera Kodeks prawa kanonicznego z 1983 roku. W kanonie II76 czytamy, że każdy wierny ma prawo do pochówku, ale powinien się on odbywać zgodnie z przepisami prawa zarówno kanonicznego, jak i liturgicznego. Ponadto istnieją różne możliwe formy pogrzebu (kan. II76 $\S_{3} \mathrm{KPK}$ ), zarówno chowanie ciał zmarłych w ziemi, jak i kremacja.

Zgodnie z wytycznymi Konferencji Episkopatu Polski także dzieci poczęte, a poronione lub martwo urodzone, niezależnie od czasu trwania ciąży mają prawo do katolickiego pogrzebu ${ }^{88}$. Zwłoki embrionów i płodów ludzkich powinny być uszanowane tak samo jak zwłoki wszystkich istot ludzkich ${ }^{39}$. Taka posta-

$3^{8}$ Komisja ds. Kultu Bożego i Dyscypliny Sakramentów Episkopatu Polski, Wstęp ogólny do Obrzędów pogrzebu, Warszawa 201 4, s. 6.

${ }_{39}$ Zob. Jan Paweł II, Przemówienie do uczestników sympozjum Papieskiej Akademii Nauk (23 października I982), „Acta Apostolicae Sedis” 75 I (I983), s. 37 . 
wa wynika z nauki Kościoła głoszącego, że z dzieckiem mamy do czynienia już od poczęcia, a nie od jakiegoś etapu rozwoju, i że należy mu się szacunek od początku jego istnienia aż do naturalnej śmierci. Konsekwencją tego stanowiska są pogrzeby dzieci zmarłych nawet na bardzo wczesnym etapie ciąży.

Prawodawca kościelny wyraźnie zaznacza, że nie można odmawiać rodzicom pochówku ich dziecka, jeśli tego pragnąa ${ }^{4}$. Niemniej Kościół nie wymaga chowania dzieci poronionych czy martwo urodzonych według religijnego obrządku ${ }^{41}$, nie jest to bowiem religijny obowiązek.

Według normy przewidzianej w kanonie II77 §ı Kodeksu prawa kanonicznego pogrzeb zmarłego dziecka powinno się odprawiać kościele parafialnym rodziców. Słuszne jest, by zgłoszenie pochówku przyjmował w kancelarii parafialnej duszpasterz osobiście w celu rozeznania, czy rodzinie zmarłego nie jest potrzebna pomoc duchowa czy materialna ${ }^{42}$. Należy pamiętać, że zgoda na pochowanie dziecka obejmuje również zgodę na mszę św. pogrzebową, przy czym jest ona raczej prośbą o pociechę dla rodziców, dlatego sprawuje się ją w szatach koloru białego ${ }^{43}$.

Zgodnie z kan. 530 pkt 5 KPK prawo i obowiązek pochówku zmarłego należy w szczególności do proboszcza parafii oraz innych osób przewidzianych przez prawo. Nie ma jednak prze-

${ }^{40}$ Zob. P. Kroczek, S. Lubaszka, Podręcznik kancelaryjny dla duchowieństwa diecezji bielsko-żywieckiej (wybrane zagadnienia), Bielsko-Biała 2006, s. 73.

${ }^{41}$ Zob. P. Kroczek, S. Lubaszka, Podręcznik kancelaryjny dla duchowieństwa..., dz. cyt., s. 73 .

${ }^{42}$ Zob. Konferencja Episkopatu Polski, Instrukcja liturgiczno-duszpasterska Episkopatu o pogrzebie i modlitwach za zmarłych, 5 V I 978, www. kkbids.episkopat.p1/?id=193 (г.03.2016).

${ }^{43}$ Zob. P. Kroczek, S. Lubaszka, Podręcznik kancelaryjny dla duchowieñstwa..., dz. cyt., s. 73 . 
ciwwskazań co do wyboru innego niż własny proboszcz szafarza pogrzebu. W gestii rodziny pozostawia się również decyzję dotyczącą miejsca pogrzebu i spoczynku zmarłego. Pochówku można dokonać na każdym cmentarzu, który nie został wyraźnie zabroniony prawem, po uprzednim uzyskaniu zgody jego zarządcy ${ }^{44}$, niemniej kanon ı180 KPK zaleca, by był to właściwy cmentarz parafialny.

Jedną z form pogrzebu dziecka nienarodzonego, dopuszczalną przez prawo, jest kremacja. O ile nie została ona wybrana $z$ motywów przeciwnych wierze, nie jest sprzeczna z nauką Kościoła ${ }^{45}$. Jednakże grzebanie ciała zmarłego lepiej wyraża wiarę i nadzieję na zmartwychwstanie w Chrystusie, niż chowanie samych tylko prochów. Decyzja o spopieleniu zwłok jest odstępstwem od wielowiekowej tradycji Kościoła. Jak czytamy w numerze 3 Dodatku do Obrzędów pogrzebu: „Prochy bowiem wyrażają zniszczenie ludzkiego ciała i nie oddają idei «snu» w oczekiwaniu zmartwychwstania. Ponadto właśnie ciału, a nie prochom, oddaje się cześć w czasie liturgii, ponieważ od chwili chrztu świętego stało się ono świątynią uświęconą przez Ducha Świętego" "46. Najnowsze uwagi dotyczące sposobu pochówku, zwłaszcza kremacji, zostały ujęte w Liście pasterskim Episkopatu Polski o szacunku dla ciała zmarłego i obrzędach pogrzebu (w przypadku kremacji). Jak czytamy w tym dokumencie, kremacja nigdy nie może pociągać za sobą praktyk, których Kościół nie akceptuje. Są nimi: rozsypywanie prochów, przechowywanie ich $\mathrm{w}$ domu, zanikanie tradycyjnych

${ }_{44}$ Zob. J. T. Martin de Agar, canon: I I 8o, [w:] Kodeks prawa kanonicznego. Komentarz, red. P. Majer, tłum. A. Wójcik, Kraków 20 I I, s. 884.

45 Zob. J. T. Martin de Agar, canon: i i 76, Kodeks prawa kanonicznego. Komentarz, dz. cyt., s. 882.

${ }^{46}$ Komisja ds. Kultu Bożego i Dyscypliny Sakramentów Episkopatu Polski, Dodatek do Obrzędów pogrzebu, Legnica 2oro, s. 6. 
cmentarzy, będących miejscem czasowego spoczynku zmarłych ${ }^{47}$. Co więcej, obrzędy pogrzebu powinny być sprawowane nad trumną z ciałem zmarłego, a tylko w razie wyższej konieczności lub jeśli przemawiają za tym szczególne racje duszpasterskie, a także powody natury praktycznej - nad urną.

Prawo polskie również dopuszcza kremację jako jedną z form pogrzebu. Sposób grzebania prochów reguluje Ustawa o zmianie ustawy o cmentarzach i chowaniu zmarłych z 201 roku ${ }^{48}$. W myśl zawartych w niej zapisów nie można w sposób dowolny przechowywać prochów osób zmarłych: trzymając w urnie w domu, zakopując w nieoznaczonym "grobie”, np. w ogrodzie, czy rozsypując w dowolnym miejscu. Jedynym dopuszczalnym miejscem pochówku są cmentarze, których organizacja jest określona stosownymi normami. Stąd też nie ma prawnej możliwości założenia prywatnego cmentarza, np. z jedną kwaterą, na własnej posiadłości.

\section{Liturgia pogrzebu dzieci zmarłych przed urodzeniem}

Dzieci poronione oraz martwo urodzone, ochrzczone lub nie, należy pochować według obrzędu przeznaczonego na pogrzeb dzieci, $\mathrm{z}$ odpowiednimi zmianami ${ }^{49}$. Jedynym kryterium roz-

${ }^{47}$ Zob. Konferencja Episkopatu Polski, List pasterski Episkopatu Polski o szacunku dla ciała zmarłego i obrzędach pogrzebu (w przypadku kremacji), I3 XI 20 I I, http://episkopat.pl/list-pasterski-episkopatu-polski-o-szacunku-dla-ciala-zmarlego-i-obrzedach-pogrzebu-w-przypadku-kremacji/ (12.03.2017).

${ }^{48}$ Ustawa o zmianie ustawy o cmentarzach i chowaniu zmarłych $\mathrm{z}$ dnia 26 maja 20 I I (Dz. U. 20 I I nr I44 poz. 853 z późn. zm.).

${ }^{49}$ Zob. P. Kroczek, S. Lubaszka, Podręcznik kancelaryjny dla duchowieństwa..., dz. cyt., s. 73 . 
różnienia dla formy pogrzebu jest chrzest dziecka. „Dziecko zmarłe przed porodem należy traktować jak dziecko zmarłe przed chrztem"so. Odnowione po Soborze Watykańskim II obrzędy pogrzebowe przewidują dla zmarłego dziecka trzy formy pogrzebu. Pierwsza zawiera trzy stacje: $\mathrm{w}$ domu, kościele i przy grobie. Druga zawiera dwie stacje: w kaplicy cmentarnej i przy grobie dziecka, nie przewiduje mszy św., która odprawiana jest w dogodnym czasie, bez obecności ciała zmarłego dziecka ${ }^{55}$. Trzecie forma pogrzebu zawiera tylko jedną stację (do wyboru) ${ }^{52}$. Odnowione obrzędy pogrzebu zrywają z tradycją pokropku, czyli jedynie pokropieniem trumny wodą święconą. Obejmują też pogrzeb dziecka, nawet jeśli miałby on mieć bardzo skromną formę.

Obrzędy pogrzebu dziecka powinny wzmacniać nadzieję i wiarę w Boże miłosierdzie oraz nieść pociech dla rodziny i bliskich. Ponieważ sam zmarły nie miał żadnych grzechów osobistych, nie używa się modlitw wstawienniczych za zmarłych. Msza święta powinna być odprawiona raczej $\mathrm{w}$ intencji rodziców, jako przejaw wsparcia ze strony Kościoła. Ponadto liturgia pogrzebowa stanowi wyraz szacunku dla godności przedwcześnie zmarłego dziecka.

Msza święta pogrzebowa odprawiana jest według podanego w mszale formularza na pogrzeb dziecka ochrzczonego bądź nieochrzczonego. Po jej zakończeniu odbywa się obrzęd ostatniego pożegnania zmarłego dziecka, w którym zostaje wyrażona

\footnotetext{
${ }^{\circ}$ Zob. P. Kroczek, S. Lubaszka, Podręcznik kancelaryjny dla duchowieństwa..., dz. cyt., s. 72 .

${ }^{5}$ Zob. Konferencja Episkopatu Polski, Obrzęy pogrzebu dostosowane do zwyczajów diecezji polskich, Warszawa 2014, s. I64.

${ }_{52}$ Zob. Konferencja Episkopatu Polski, Obrzędy pogrzebu dostosowane..., dz. cyt, s. I I 5 .
} 
wiarę, że skoro Chrystus zmartwychwstał, to również wskrzesi to dziecko, gdy przyjdzie w chwale ${ }^{53}$.

Po obrzędach pogrzebu należy sporządzić odpowiednią adnotację w księdze zmarłych, jak to nakazuje kanon II82 KPK oraz określają szczególowo przepisy prawa partykularnego. Obowiązek ten należy do parafii własnej rodziców dziecka. Stąd też, jeżeli pogrzeb nie odbywał się w kościele parafialnym, należy powiadomić o nim właściwego proboszcza ${ }^{54}$.

\section{Możliwość pochówku dzieci zabitych podczas aborcji i procedury in vitro}

Szczególnym przypadkiem pochówku jest pogrzebanie szczątków dziecka pochodzących $z$ aborcji, a także zarodków powstałych na skutek zapłodnienia in vitro, które zginęły na wczesnym etapie ciąży lub nigdy nie zostały zaimplementowane.

Celem precyzyjnego omówienia tego zagadnienia należy na wstępie zdefiniować kilka pojęć i umieścić je we właściwym kontekście. Po pierwsze, aborcję, czyli przerwanie ciąży, rozumiemy tutaj jako poronienie sztuczne, czyli wywołane czynnikiem zewnętrznym wobec organizmu matki i dziecka ${ }^{55}$. Dokonuje się jej

${ }_{53}$ Zob. Konferencja Episkopatu Polski, Obrzędy pogrzebu dostosowane do zwyyczajów diecezji polskich, Warszawa 20 I4, s. I I . Teksty modlitw odmawianych podczas mszy świętej pogrzebowej znajdują się w Mszale Rzymskim pod numerami 4I (pogrzeb dziecka ochrzczonego) i 42 (pogrzeb dziecka nieochrzczonego).

${ }^{54}$ Zob. J. T. Martin de Agar, canon: I I 80, [w:] Kodeks prawa kanonicznego. Komentarz, dz. cyt., s. 884.

${ }_{55}$ Zob. M. Zubik, Problem aborcji w dokumentach i orzecznictwie sqdowym, Warszawa I 997, s. 4-5. 
za zgodą matki, a jej skutkiem jest śmierć płodu. Obowiązująca obecnie w Polsce Ustawa o planowaniu rodziny, ochronie płodu ludzkiego i warunkach dopuszczalności przerywania ciąży z dnia 7 stycznia $1993 \mathrm{r}^{.6}$ delegalizuje aborcję poza trzema przypadkami (art. 4a ust. I). Chodzi o sytuację zagrożenia życia lub zdrowia kobiety ciężarnej, diagnozę nieodwracalnego, ciężkiego uszkodzenia płodu lub nieuleczalnej choroby zagrażającej jego życiu, oraz podejrzenie, że ciąża jest wynikiem czynu zabronionego. W dwóch pierwszych sytuacjach możliwe jest dokonanie aborcji do czasu osiągnięcia przez płód zdolności samodzielnego życia poza organizmem matki. W przypadku ciąży zastniałej wskutek czynu zabronionego płód może być usunięty, jeśli ciąża trwa nie dłużej niż I2 tygodni. Warto podkreślić, że użycie w ustawie pojęcia „prawo” nie tworzy prawa podmiotowego do przerywania ciąży w okolicznościach określonych ustawą. Intencją prawodawcy było jedynie uchylenie karalności czynów zabronionych przez Kodeks karny ${ }^{57}$.

Zastanawiając się nad pochówkiem szczątków powstałych $\mathrm{w}$ czasie procedury in vitro, trzeba podjać refleksję na temat początków życia człowieka. Ponadto należy ujmować zarodki powstałe na skutek sztucznego zapłodnienia w kategoriach personalistycznych, ponieważ jeśli będzie się je postrzegać jako osoby, to nie będzie można zaprzeczyć przysługującym im prawom oraz godności. Rodzice rezygnujący z kolejnych inseminacji stają wobec problemu embrionów niewykorzystanych w procedurze sztucznego zapłodnienia.

\footnotetext{
${ }^{56}$ Ustawa o planowaniu rodziny, ochronie płodu ludzkiego i warunkach dopuszczalności przerywania ciąży z dnia 7 stycznia I 993 r., (Dz. U. nr I7 poz. 78 z późn. zm.).

57 Zob. B. Imielska, Umartych pogrzebać. Zagadnienie pochówku dzieci poronionych lub martwo urodzonych w prawie kanonicznym oraz ustawodawstwie polskim, Bielsko-Biała 2O I 4, s IO2.
} 
Podstawą postulatu zakazującego manipulacji i dokonywania doświadczeń na ludzkich embrionach w celach naukowych jest uznanie, iż są one żywymi ludźmi ${ }^{8}$. Wszelkie tego typu działania są tym bardziej zakazane, jeżeli wiążą się z koniecznością zniszczenia embrionów lub ich użycia jako materiału wyjściowego do dalszych doświadczeń. Poszanowanie ludzkiej godności wyklucza jakiekolwiek eksperymenty dokonywane na ludzkich embrionach ${ }^{59}$.

W prawodawstwie polskim w przypadku pochówku szczątków dzieci zmarłych na skutek aborcji lub procedury in vitro stosuje się Ustawę o odpadach z I4 grudnia 2012 r. ${ }^{60}$. W świetle zawartych w niej zapisów odpadami medycznymi są ludzkie tkanki czy organy, które powstają podczas udzielania świadczenia zdrowotnego (w tym aborcji i procedury in vitro). Traktuje się je jako odpady szczególnie niebezpieczne (kod I8oro3). A zatem płód, będący odpadem postaborcyjnym, musi zostać poddany procesowi spopielenia ${ }^{6 r}$.

Pojawia się tutaj jednak pewna wątpliwość, ponieważ tkanki dzieci nie są tożsame $z$ organizmem matki i nie mieszczą się w definicji odpadu medycznego, powstałego na skutek udzielenia świadczenia. A zatem mamy do czynienia nie z tkankami, lecz

${ }^{8}$ Zob. A. Bielecki, Embrion ludzki w kontekście wyroku Trybunatu Sprawiedliwości UE - sprawa Bruestle vs Greenpeace, http://iusetmedicina.wordpress. $\mathrm{com} / 20$ I I/ Io/29/embrion-ludzki-w-kontekscie-wyroku-trybunalu-sprawiedliwosci-ue-sprawa-bruestle-v-greenpeace/ ( I 2.03.20I 7).

${ }_{59}$ Zob. A. Dzięga, Karta Praw Rodziny. Aktualnośc przestania, www.pedkat.pl/in dex.php/309-karta-praw-rodziny-aktualnosc-przeslania\#_ftn2 2, (I 2.03 .2017 ).

${ }^{60}$ Ustawa $z$ dnia I 4 grudnia 20 I 2 r. o odpadach (Dz.U. 20 I 3 nr o poz. 2 I z późn. zm.).

${ }^{61}$ Ustawa z dnia 14 grudnia 2012 r. o odpadach (Dz.U. $2013 \mathrm{nr}$ o poz. 2 I z późn. zm.). 
ze zwłokami, zgodnie z definicją zawartą w $\$ 2$ rozporządzenia Ministra Zdrowia z 20II r. w sprawie postępowania ze zwłokami i szczątkami ludzkimi.

Nie istnieją jednak jasne przeciwwskazania, by wobec dziecka zmarłego na skutek aborcji nie stosować przepisów dotyczących poronienia. Rozwiązanie takie wydaje się słuszne, gdyż dziecko zabite na skutek aborcji w niczym ontologicznie i substancjalnie nie różni się od dziecka poronionego czy martwo urodzonego, a zatem nie istnieja podstawy do odmowy uprawnionym podmiotom prawa do pochówku.

Również w kontekście procedury in vitro pojawia się konieczność zwrócenia uwagi na sposób traktowania powstałych w ten sposób ludzkich istot. Rodzice rezygnując z inseminacji zarodków stają przed problemem, co zrobić z zarodkami niewykorzystanymi, zamrożonymi, które przecież są ich dziećmi. Pojawia się również problem, co zrobić z zarodkami, które zostały wprowadzone do organizmu matki, ale uległy poronieniu. Jak je traktować? Jako odpad medyczny po nieudanym świadczeniu medycznym czy raczej jako szczątki ludzkie?

Kolejną kwestią wymagającą regulacji jest sytuacja, w której rodzice chcą odzyskać od kliniki zajmującej się zabiegami in vitro swoje zamrożone zarodki w celu ich pochowania. Teoretycznie klinika mogłaby wydać embriony rodzicom. Jednak, ponieważ nie ma prawa, które regulowałoby tę sprawę, istnieje poważny problem z wystawieniem karty zgonu, zwłaszcza że zarodki te nigdy nie były wszczepione do organizmu matki, a zatem nigdy nie było ciąży. Wydaje się, że w tym kontekście należy stosować przepisy zawarte w Ustawie o odpadach ${ }^{62}$, według której wszelkie

\footnotetext{
${ }^{62}$ Ustawa $\mathrm{z}$ dnia I4 grudnia 2012 r. o odpadach (Dz. U. $2013 \mathrm{nr}$ o poz. 2 I z późn. zm.).
} 
formy zdolne do przeniesienia materiału genetycznego, powstałe na skutek szeroko pojętych świadczeń medycznych, muszą być unieszkodliwione poprzez przekształcenie termiczne (spopielenie). Zapis ten pośrednio uniemożliwia wydanie ludzkich zarodków rodzicom w celu pochówku ${ }^{63}$.

\section{Zakończenie}

Omawiając zagadnienie pochówku dzieci poronionych i martwo urodzonych, należy przede wszystkim dostrzec złożoność tego zagadnienia. Składają się na nie nie tylko kwestia prawna, medyczna czy psychologiczna, ale przede wszystkim całe spektrum ludzkich emocji. Stąd też w podsumowaniu trzeba sformułować pewne postulaty.

Trzeba stwierdzić, że niestety mamy do czynienia z fikcją, w której rodzice, pomimo zagwarantowanych im prawem uprawnień, nadal w znacznym stopniu uzależnieni są od dobrej woli personelu medycznego w danym szpitalu. Często odmawia się im prawa do informacji albo udziela się ich wybiórczo, lub niezgodnie z prawdą, i to jeszcze wtedy, gdy są w szoku. Niejednokrotnie też wywiera się psychologiczną presję na kobiecie będącej pod wpływem strachu i zależnnej od personelu ${ }^{64}$.

Niedoskonała jest również kontrola nad tym, co dzieje się z elementami materiału medycznego, który pozostał po wykonanym świadczeniu medycznym. Brak przejrzystych i ujednoliconych zasad postępowania niejednokrotnie uniemożliwia wykonanie

${ }_{63}$ Zob. Ustawa z dnia 3 I stycznia r 959 r. o cmentarzach i chowaniu zmarłych (Dz. U. I 959 nr i I poz. 62 z późn. zm.).

${ }_{64}$ Zob. www.poronienie.pl/prawo/prawo-w-pigulce/ (I.o3.20I6). 
niezbędnych badań, np. mających na celu określenie płci dziecka, które jest konieczne do wydania dokumentacji dla celów pochówkowych. Nie ma także procedur zapobiegających utracie szczątków dziecka, niezachowanie zaś w tym względzie należytej staranności nie pociąga za sobą żadnych konsekwencji prawnych.

Niekiedy, zwłaszcza gdy do poronienia doszło na wczesnym etapie ciąży, nie jest zagwarantowane żadne z przysługujących rodzicom praw. Ich realizacja zostaje uniemożliwiona tylko dlatego, że utracone zostają szczątki umożliwiające wykonanie koniecznych badań, rejestrację oraz pochówek. Ponadto nie ma stosownych przepisów, precyzujących obowiązek szpitala określenia płci dziecka na własny koszt. W konsekwencji za badania wymagane do rejestracji dziecka płacą rodzice, ponieważ szpitale odmawiają wykonywania ich we własnym zakresie. Wynika to z faktu, że badania te nie są świadczeniami zdrowotnymi i dlatego nie są refundowane przez NFZ. W rezultacie niektórzy rodzice muszą ponosić dodatkowe koszty, aby skorzystać z ustawowych praw do pochówku własnego dziecka ${ }^{65}$.

Omawiany problem skłania do wysunięcia następujących wniosków: po pierwsze, zagadnienia pochówku dzieci poronionych i martwo urodzonych nie można traktować marginalnie, ponieważ stawia nas ono wobec pytań o podstawowe prawdy dotyczące człowieka, m.in. jak rozumiemy początek ludzkiego życia oraz kim jest osoba jako taka.

Po drugie, tylko koncepcja traktująca zapłodnienie jako początek życia człowieka pozwala na utrzymanie w mocy prawa do pochówku płodów poronionych, także na skutek aborcji czy procedury in vitro, oraz niezaimplementowanych zarodków.

${ }_{65}$ Zob. www.poronienie.pl/prawo/prawo-w-pigulce/ (I.03.2016). 
Po trzecie, należałoby wypracować na gruncie prawa polskiego takie rozwiązania prawne, które wychodząc naprzeciw potrzebom rodziców, gwarantowałyby im prawo pochówku szczątków własnego dziecka bez względu na okoliczności jego śmierci.

Wydaje się jednak, że najważniejszym postulatem jest konieczność dokonania mentalnej zmiany w podejściu do pochówku dzieci nienarodzonych i martwo urodzonych. Tylko dzięki temu możliwe będzie ukazanie doniosłości tego wydarzenia nie tylko dla najbliższej rodziny zmarłego, ale również na tle społecznym i kulturowym. Istotna tutaj jest rola Kościoła stojącego na straży integralnego pojmowania życia człowieka jako trwającego od poczęcia aż do śmierci. Tylko właściwe ukazanie pochówku dziecka poronionego czy martwo urodzonego umożliwi zachowanie harmonii pomiędzy ochroną ludzkiego życia od poczęcia do naturalnej śmierci i godnym traktowaniem doczesnych szczątków ludzkich, uzasadnionej argumentami prawnymi, medycznymi, moralnymi, psychologicznymi i teologicznymi.

Barbara Imielska, Pogrzeb dzieci poronionych i martwo urodzonych w świetle przepisów prawa polskiego oraz norm kanonicznych, [w:] Pogrzeb w prawie kanonicznym i prawie świeckim, red. Elżbieta Kruk, Kraków 20I9, s. 45-7I. DOI: http://dx.doi.org./Io.15633/9788374387446.04 
4. Uniwersytet Papieski

Tfig: Jana Pawła II

w Krakowie 